\title{
АЛГОРИТМ ВИЗНАЧЕННЯ ЕЛЕКТРОМАГНІТНОЇ СУМІСНОСТІ ДЛЯ РІШЕННЯ ЗАДАЧ ЧАСТОТНОГО ПЛАНУВАННЯ
}

Анотація. Інтенсивний розвиток сфери телекомунікацій безпосередньо пов'язаний $з$ впровадженням у практику новітніх радіотехнологій і систем зв'язку, появою нових послуг і видів зв'язку. В цих умовах забезпечення потреб у радіочастотному ресурсі усіх категорій користувачів здійснюється за рахунок перерозподілу вже освоєних i подальшого освоєння нових діапазонів частот. Перерозподіл частот, у свою чергу, призводить до збільшення навантаження на вже освоєні діапазони, що зумовлено зростанням кількості діючих радіоелектронних засобів, і до ускладнення електромагнітної обстановки. Освоєння нових діапазонів диктує необхідність виділення смуг радіочастот для новітніх радіотехнологій, систем і стандартів зв'язку. В цих умовах задачі управління РЧР і забезпечення електромагнітної сумісності радіоелектронних засобів та випромінювальних пристроїв мають важливе практичне значення.

Дані задачі можуть бути вирішені тільки при реалізації відповідного науковометодичного апарату радіомоніторингу, застосування якого дало б змогу ефективного використання радіочастотного ресурсу в сучасних умовах. Тому тема дипломної роботи $\epsilon$ актуальною.

У роботі викладено причини виникнення взаємних завад при роботі радіоелектронних засобів в ускладненій радіоелектронній обстановці, розглянуто сучасний науково-методичний апарат радіомоніторингу з визначенням в цьому місці електромагнітної обстановки для вирішення частотного планування РЕЗ .

Ключові слова: джерело радіовипромінення, електромагнітна обстановка, електромагнітна сумісність, пункт технічного радіоконтролю, радіовипромінюючий пристрій, радіорегламент, радіотехнології, радіочастотний ресурс.

\section{Вступ}

У роботі проведено аналіз причин виникнення взаємних завад при роботі радіоелектронних засобів в ускладненій радіоелектронній обстановці, розглянуто сучасний науково-методичний апарат радіомоніторингу з визначенням в ньому електромагнітної обстановки для вирішення задач частотного планування РЕЗ рухомої служби.

Об’єкт дослідження - процес визначення електромагнітної обстановки для вирішення задач частотного планування радіоелектронних засобів рухомої служби.

Предмет дослідження - дослідження та розрахунок ЕМС РЕЗ в районі планування.

(c) I. Р. Пархомей, В. В. Недолужко 
Мета роботи. Дослідження ефективності використання та визначення напрямків удосконалення розрахуноку ЕМС РЕЗ в районі планування.

Методика припускає проведення аналізу ЕMC PE3 у районі планування, а у випадку використання загальної площадки для розміщення РЕЗ - ЕМС локального угруповання РЕ3 (об'єктова ЕМС).

У першому випадку враховуються завади наступних видів [1]:

- по основному каналу;

- по першому сусідньому каналу;

- завади інтермодуляції 3-го порядку.

В другому випадку, крім перерахованих вище, враховуються завади наступних видів [2]:

- по сусідніх каналах;

- інтермодуляція вище 3-го порядку (до 13-го порядку включно);

- блокування;

- по дзеркальному каналу;

- по першій ПЧ;

- на гармоніках.

При проведенні аналізу, вищезазначеної методики був встановлений показник ефективності цієї методики, при менших витратах на виміри електромагнітної обстановки, та рекомендовано для широкого використання цієї методики, при контролю та управління радіочастотним ресурсом і забезпечення електромагнітної сумісності радіоелектронних засобів.

\section{Основна частина}

Інтенсивний розвиток сфери телекомунікацій безпосередньо пов'язаний 3 упровадженням у практику нових радіотехнологій і систем зв'язку, появою нових послуг і видів зв'язку. В цих умовах забезпечення потреб у радіочастотному ресурсі усіх категорій користувачів здійснюється за рахунок перерозподілу вже освоєних і подальшого освоєння нових діапазоні в частот.

Перерозподіл частот, у свою чергу, призводить до збільшення навантаження на вже освоєні діапазони радіочастот, що зумовлено зростанням кількості діючих РЕЗ, і до ускладнення електромагнітної обстановки. Освоєння же нових діапазонів частот диктує необхідність виділення смуг радіочастот для нових радіо технологій, систем і стандартів зв'язку. В цих умовах управління РЧР і забезпечення електромагнітної сумісності (ЕМС) РЕЗ та випромінювальних пристроїв (ВП) мають важливе практичне значення.

Разом 3 тим, в останні роки розробники та виробники засобів телекомунікацій приділяють значну увагу вищим діапазонам радіочастот, які вважаються 
найперспективнішими для практичного освоєння. На цей час в Україні діапазон радіочастот 3,5 ГГц інтенсивно освоюється радіотехнологій WiMAX, діапазони радіочастот 6/4 ГГц, 8/7 ГГц, 14/11 ГГц і 30/20 ГГц насичуються супутниковими системами зв'язку.

Складність вирішення завдань радіомоніторингу в діапазонах частот понад 3 ГГц зумовлена:

- труднощами виявлення, визначення місцезнаходження ДРВ і вимірювання параметрів їхнього радіовипромінювання;

- відмінностями законодавчого регулювання використання РЧР в Україні від ряду європейських країн;

- відсутністю необхідного технічного обладнання й відповідного нормативно-методичного забезпечення радіомоніторингу.

Незважаючи на велике різноманіття радіослужб, радіотехнологій, систем і стандартів зв'язку, які нині існують у світі, на практиці для вирішення завдань радіомоніторингу можна використовувати обмежену кількість методів. Це положення радіо технологій на можливості об'єднання радіо технологій, систем зв'язку в групи за певними критеріями, що сприятиме застосуванню єдиних методів виявлення радіовипромінювань, вимірювання їхніх параметрів, пеленгування та визначення місцезнаходження ДРВ тощо. Залишається лише визначити критерії такої класифікації, розподілити системи радіозв'язку на групи за цими критеріями, відмітити для кожної iз груп властиві їй методи радіомоніторингу та перелік технічних параметрів, які потрібно вимірювати та (чи) визначати під час його проведення. На практиці, говорячи про радіомоніторинг, часто мають на увазі дещо інші поняття, зокрема, контроль параметрів радіосигналів у високочастотних трактах.

До технічних характеристик РЕЗ відносяться [3]:

- потужність передавального пристрою;

- частота передачі;

- частота прийому;

- спектр (частотна маска) сигналу передавача;

- клас випромінювання;

- азимут максимального випромінювання антени;

• коефіцієнт підсилення антени, іії тип і поляризація випромінювання;

- діаграма спрямованості антени;

- висота підвісу антени;

- величина необхідного захисного відношення;

- необхідна надійність зв'язку при відсутності завад.

Технічні характеристики РЕЗ, який планується, можуть бути отримані 3 матеріалів радіочастотної заявки, поданої заявником, а РЕЗ, що беруть участь у розрахунках ЕMС у регіоні планування, із загальної бази даних частотних присвоєнь. 
Міжвідомчий науково-технічний збірник «Адаптивні системи автоматичного управління» № 2' (33) 2018

В основі процедури підбору частот для РЕЗ лежить аналіз ЕМС РЕ3, який полягає в розрахунку ЕМС в районі планування та ЕМС локального угрупування PE3 (об'єктова ЕMC).

Розрахунок ЕМС РЕЗ в районі планування виконується в наступному порядку:

а) вибір по територіальній ознаці РЕЗ, розташованих в області обмеженої зони дослідження;

б) вибір із РЕ3, які обрані по територіальній ознаці, по частотній ознаці тих PE3, що потенційно заважають новому частотному присвоєнню:

- визначення можливих джерел завад по основному каналу;

- визначення джерел завад по першому сусідньому каналу;

- визначення можливих джерел завад інтермодуляції 3-го порядку.

в) розрахунок рівня завад на вході приймача:

- по основному каналу;

- по першому сусідньому каналу;

- інтермодуляції 3-го порядку;

г) аналіз отриманих результатів та ухвалення рішення за результатами розрахунків про можливість частотного присвоєння з урахуванням впливу множинної завади або необхідності вибору іншої частоти.У випадку позитивного рішення щодо можливості частотоприсвоєння за результатами розрахунку ЕМС, необхідно перевірити наявність інших РЕЗ на спільному майданчику та, при наявності таких, провести розрахунок ЕМС локального групування РЕЗ (об'єктова ЕМС).

ЕМС локального угрупування РЕЗ виконується в наступному порядку:

а) серед РЕЗ, відібраних відповідно $з$ попереднім пунктом вибираються PE3, які розташовані в межах спільного майданчика в колі радіусом до 1 км від БС, що досліджується. Величина радіусу 1 км обумовлена наступним припущенням - втрати при розповсюдженні радіохвиль для цієї відстані складають 60 $\div 100$ дБ (модель розповсюдження у вільному просторі) у залежності від частотного діапазону, що зводить до мінімуму імовірність впливу на приймач інших видів завад на великих відстанях від передавача. Всі станції, що потрапили в зону, обмежену цим колом, вибираються для проведення подальшого аналізу.

б) РЕЗ, які потенційно можуть створювати завади прийому БС, що досліджується, або підпадають під дію її завади, відбираються по частотній ознаці серед РЕЗ, вибраних по територіальній ознаці. Для кожного з відібраних передавачів (чи групи передавачів) перевіряється частотна умова можливості створення завади досліджуваному приймачеві або для кожного з відібраних приймачів по групі відібраних передавачів перевіряється частотна умова можливості постановки завад від досліджуваного передавача по наступним видах завад:

- по сусідніх каналах; 
- по інтермодуляції 3-го - 13-го порядків;

- по дзеркальному каналу;

- по першій ПЧ;

- на гармоніках;

- по блокуванню;

в) розраховуються рівні для кожного виду завади;

г) здійснюється аналіз отриманих результатів i, за результатами розрахунків, приймається рішення про можливість частотного присвоєння з урахуванням впливу множинної завади або необхідність вибору іншої частоти.

Загальний алгоритм проведення частотоприсвоєння для РЕЗ приведений на рис. 1.

Для вибору станцій, які характеризують електромагнітну обстановку в місці передбачуваного нового частотоприсвоєння, необхідно визначити розміри розрахункової зони. Для цього необхідно окреслити коло 3 центром в точці з координатами нового частотоприсвоєння (BS) і радіусом, рівним подвоєному радіусу заявленої зони обслуговування (2d) [4], або відповідній відстані згідно стандарту для даного виду зв'язку та діапазону частот (рис.2)

Всі станції, що потрапили в простір, обмежений цим колом (рухомі, спільно зі своїми базовими, навіть якщо останні не потрапили в цю область), вибираються для подальшого аналізу на виконання частотних вимог.

Незважаючи на всю різноманітність факторів, які впливають на якість прийому сигналів, класичним підходом у визначенні якості функціонування РЕЗ $€$ оцінка енергетичного відношення сигнал/(завада+шум) при заданих показниках. Тому за основний критерій оцінки параметрів ЕMC PE3 прийнятий енергетичний критерій, виражений за допомогою відношення сигнал/завада при заданих показниках якості:

$$
\frac{P_{S}}{P_{I}} \geq \mathrm{A}(\Delta f)=A_{0} * \operatorname{FDR}(\Delta f),
$$

де $A(\Delta f)$ - захисне відношення при даному частотному розстроюванні $\Delta \mathrm{f}$ між корисним сигналом та завадою; $A_{0}$ - захисне відношення по сполученому каналу; $\operatorname{FDR}(\Delta f)$ - коефіцієнт, який характеризує ослаблення завади в залежності від частотного розстроювання між корисним сигналом і завадою; $P_{S}$ - потужність корисного сигналу на вході приймача, підданого впливу завад; $P_{I}$ - потужність завади на вході приймача, підданого впливу завад. 
Міжвідомчий науково-технічний збірник «Адаптивні системи автоматичного управління» № 2’ (33) 2018

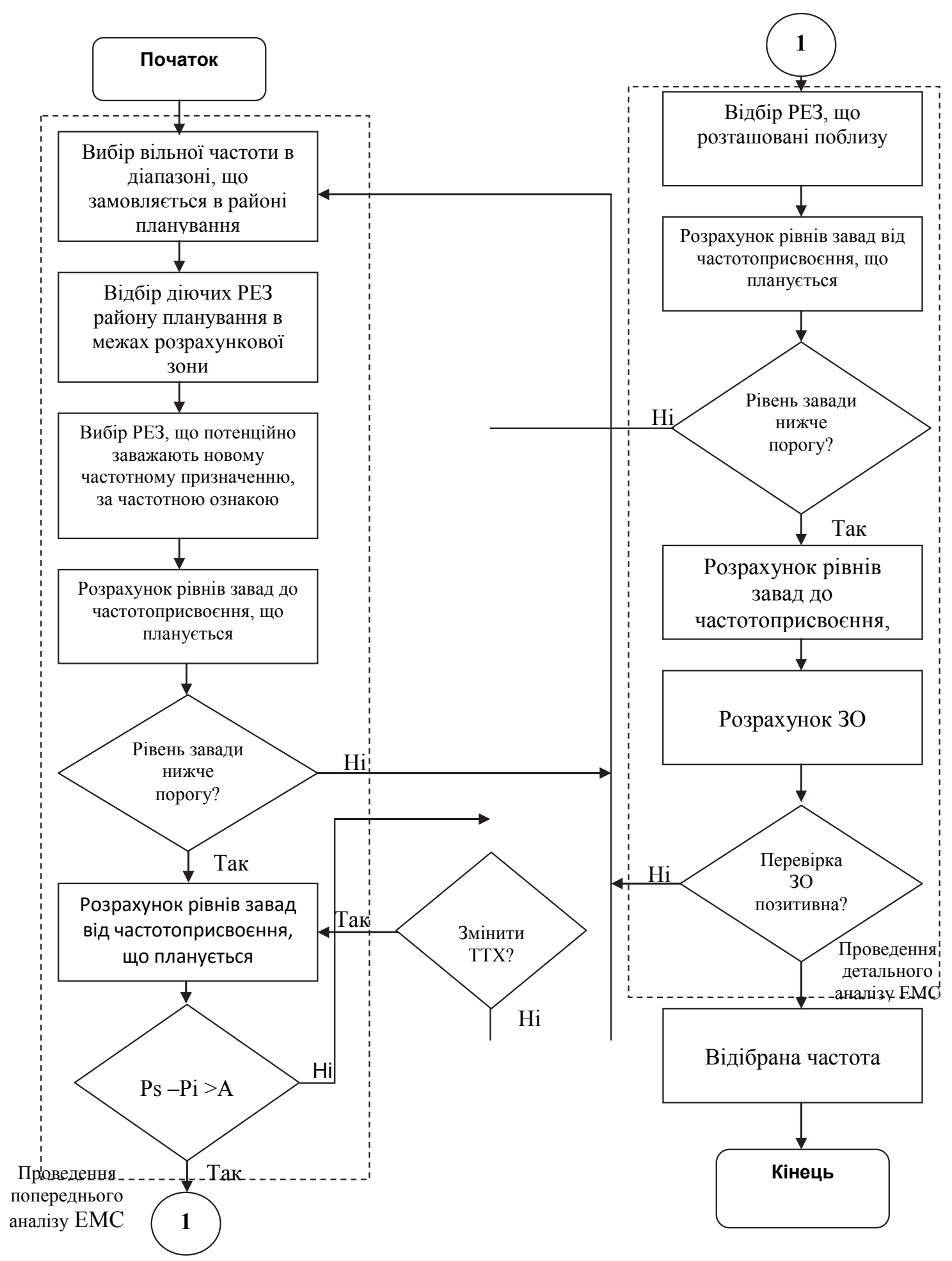

Puc. 1 Загальний алгоритм підбору частот для РЕЗ 


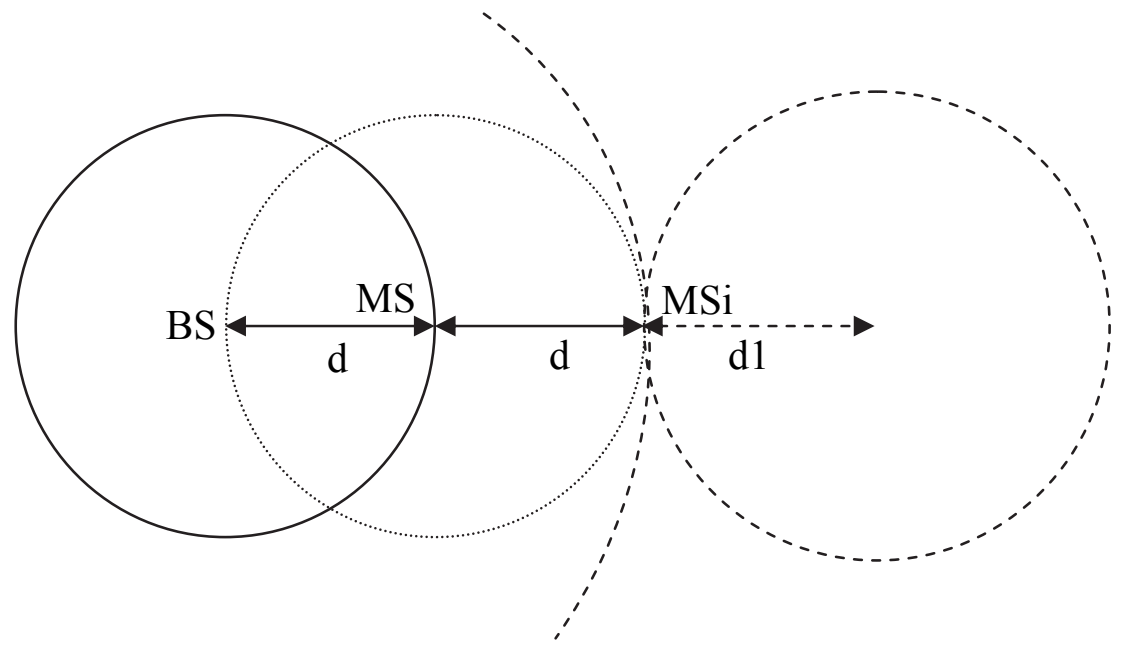

Puc. 2. Вибір завадонебезпечних РЕ3

Вплив середовища на розповсюдження радіохвиль, в силу випадкової природи незліченної кількості причин, виявляється в зміні амплітуди поля хвилі, зміні швидкості і напрямку розповсюдження хвилі, у повороті площини поляризації хвилі та інших спотвореннях сигналу. Тому флуктуації рівнів корисного сигналу на вході приймача також є випадковою величиною.

Рухомий зв'язок характеризується великими змінами напруженості поля, як функції місця розташування і часу. Ці зміни можуть бути описані логнормальним розподілом зі стандартним відхиленням 8 дБ у діапазоні $30-300$ МГц і 10 дБ у діапазоні 300-3000 МГц [5].

Конкретне значення величини необхідного захисного відношення $є$ характеристикою досліджуваної системи рухомого зв'язку (стандарту рухомого зв'язку) і задається в вигляді вихідних даних при аналізі ЕМС.

\section{Висновок}

Викладено причини виникнення взаємних завад при роботі радіоелектронних засобів в ускладненій радіоелектронній обстановці, розглянуто сучасний науково-методичний апарат радіомоніторингу 3 визначенням в ньому електромагнітної обстановки для вирішення задач частотного планування РЕЗ рухомої служби.

Методика припускає проведення аналізу ЕМС PE3 у районі планування, а у випадку використання загальної площадки для розміщення РЕ3 - ЕМС локального угруповання РЕЗ (об'єктова ЕМС).

У першому випадку враховуються завади наступних видів :

- по основному каналу;

- по першому сусідньому каналу;

- завади інтермодуляції 3-го порядку. 
В другому випадку, крім перерахованих вище, враховуються завади наступних видів :

- по сусідніх каналах;

- інтермодуляція вище 3-го порядку (до 13-го порядку включно);

- блокування;

- по дзеркальному каналу;

- по першій ПЧ;

- на гармоніках.

При проведенні аналізу, вищезазначеної методики був встановлений показник ефективності цієї методики, при менших витратах на виміри електромагнітної обстановки, та рекомендовано для широкого використання цієї методики, при контролю та управління радіочастотним ресурсом i забезпечення електромагнітної сумісності радіоелектронних засобів

\section{Список використаних джерел}

1. Recommendation ITU-R P.341-4. The concept of transmission loss for radio links.

2. Recommendation ITU-R SM.337-4. Frequency and distance separations.

3. Recommendation ITU-R PN.525-2. Calculation of free-space attenuation.

4. Bornemann W. [2011] Aerial Installation on Naval Ship. Summary of the paper presented at Antenna Conference, Karlskrona.

5. Humennyi, D Parkhomey, I., Tkach, M. Structural model of robotmanipulator for the capture of non-cooperative client spacecraft .Volume 754, 2019, Pages 33-421st International Conference on Computer Science, Engineering and Education Applications, ICCSEEA2018; Kiev; Ukraine; 18 January 2018 